\title{
THE LABOR-MANAGEMENT RELATIONSHIP: PRESENT DAMAGES FOR LOSS OF FUTURE CONTRACTS*
}

ON April 30, 1957, the Brooks Shoe Manufacturing Company closed the doors of its Philadelphia factory for the last time, and thereby completed a three year moving process to Hanover, Pennsylvania. The union which represented thirty-three workers left behind by the transfer brought suit under section 301 of the Taft-Hartley Act. ${ }^{1}$ The court held that the removal was a breach of the collective bargaining agreement, ${ }^{2}$ and observed that had these facts been before the National Labor Relations Board, Brooks would have been found guilty of committing an unfair labor practice. Three items of damages were awarded to the union as an entity: $\$ 50,000$ punitive damages; 4 $\$ 4,251$ compensatory damages representing the dues the union would have collected from April 30, 1957, the date of the breach, to September 22, 1960, the date of decision; 5 and $\$ 23,760$ for compensatory damages representing the dues lost to the union for the next twenty years. ${ }^{6}$ The contract breached by the removal had been made early in 1957, and was to have terminated on December 31, 1957, eight months after the removal was completed and thirty-three months before the decision. ${ }^{7}$

The award of damages for lost future dues rests upon the assumption that parties to a present contract may have an interest in future contracts between

*United Shoe Workers v. Brooks Shoe Mfg. Co., 187 F. Supp. 509 (E.D. Pa. 1960).

1. Labor Management Relations Act § 301(b), 61 Stat. 156 (1947), 29 U.S.C. \& 185(b) (1958).

2. The findings of fact and the decision that Brooks was in breach of contract are reported in United Shoe Workers v. Brooks Shoe Mfg., Co., 183 F. Supp. 568 (E.D. Pa. 1960).

3. A separate opinion devoted solely to the issue of damages is reported in United Shoe Workers v. Brooks Shoe Mfg. Co., 187 F. Supp. 509 (E.D. Pa. 1960). An appeal from this decision was docketed, No. 13421, 3d Cir., Oct. 12, 1960, and was argued on November 14, 1961. This Note is written between the argument and the decision.

4. $187 \mathrm{~F}$. Supp. at 512. For critical analyses of this item of damages, see Note, 34 TeMp. L.Q. 136 (1961); Note, 109 U. PA. L. Rev. 762 (1961); and Note, 47 CoRNedL L.Q. 112 (1961).

5. $187 \mathrm{~F}$. Supp. at 510-11.

6. For a period of twenty years plaintiff-union has successfully negotiated contracts with defendant and represented thirty-three employees at the time of the breach from whom plaintiff received monthly dues. Due to the wilful breach plaintiff has not only lost the right to receive these dues for an indefinite period in the future, but its reputation as a bargaining agent has been seriously jeopardized. Considering the contractual relationship over that twenty-year period, in conjunction with modern and accepted labor management relations, it is only reasonable to assume that had there been no breach, plaintiff-union would have continued to represent the employees of the defendant-company for a similar period in the future with the resultant beneId. at 511 . fits therefrom.

7. Ibid. 
themselves even without an express provision to that effect, and that the law should protect this interest under certain circumstances. The argument ${ }^{8}$ for such protection is probably strongest when the Brooks circumstances are present: the parties had been engaged in the kind of continuing contractual association which created a real probability of future contracts; ${ }^{9}$ one party, from necessity, ${ }^{10}$ had changed his position in reliance upon this probability; and the other party elected to do something "improper" which separated the parties forever, thereby destroying the probability.

These circumstances occur primarily in the labor-management, exclusive dealership, and sales agency areas, where parties, in order to perform obligations under existing contracts, frequently make large investments which can only be recaptured if the contractual relationship is not severed after the termination of the present contract. Labor unions often build permanent facilities in certain cities to service members working there, even though all their present agreements may have short periods to run. Manufacturers, in order to meet present expenses, usually make long-term sales agreements even though many are not to be performed fully until after present labor agreements expire. When one party suddenly ends such a relationship, the other can often be seriously injured. It is not enough, however, for a court to decide that an innocent party's opportunity to negotiate future contracts should, under these circumstances, be protected; it should construct a legal justification upon which to base that protection. This requirement presents three basic problems: traditional doctrines dealing with interests in future contracts must be distinguished; a theory imposing an "obligation implied in law" must be adopted; and a method of measuring a party's interests in future contracts must be developed. The Brooks decision is disturbing in its silence on these problems.

\section{Distinguishing Traditional Contract Doctrine}

Brooks is apparently the first case in which an award of damages for breach of contract has been made upon the express assumption that future contracts between plaintiff and defendant would have materialized had the

8. Economic or general policy considerations underlying the argument that parties' interests in future contracts should be protected are beyond the scope of this Note. Some of them will be discussed in a Yale Law Joutrnal Comment now in preparation, dealing with the effects of plant removals upon employees' interests in the retention of seniority privileges beyond the end of present contracts.

9. Such a relation should be distinguished from the simple contract, in which two parties come together to execute a single transaction, and then go their separate ways forever. A modern economy, of course, does not proceed with such short, choppy steps. It surges forward upon long strides, affected by single long-term contracts or successions of shorter ones.

10. The protection of necessary expenses made in reliance on future contracts probably could be justified more easily than avoidable expenses made completely by choice. At least when the investment is not made by choice there can be no argument that the injured party chose to take the risk of injury - that he "bet" on future contracts and lost. 
breach not occurred, ${ }^{11}$ absent an option to renew. ${ }^{12}$ Decisions awarding damages for breach of contract between parties in continuing associations analogous to that between Brooks and the union expressly deny the kind of damages awarded in Brooks. These cases were decided upon the basic tenet of contract law that the intent of the parties as expressed in the agreement is controlling. Termination provisions have been universally construed to express the intended duration of the parties' contractual obligations. ${ }^{13}$

Damages to individual workers for breach of collective bargaining agreements traditionally have been limited to those accruing at the earliest date the agreement could rightfully be terminated.14 Damages for breach of individual employment contracts containing a termination date are limited to the balance of the term remaining after the breach. ${ }^{15}$ If the contract has no set termination date, but merely permits either party to terminate by giving notice a certain period in advance, damages are awarded only for the length of the notice period. ${ }^{16}$ Where both a termination date and notice period are

11. This problem is to be distinguished from the traditional award of "lost profits" for seller's breach of a sales contract. It is true that the buyer's profits are based upon future resale contracts, but "lost profits" is merely a description of his expectation interest in the present contract with defendant. Here we deal with the value of plaintiff's interest in future contracts with defendant, a value conveniently called "probability."

12. When the contract contains an option to renew, damages for the loss of the innocent party's interests in that contract include the value of the option. But the damages measure the value of the option itself, not the value of the future contract that an exercise of the option might have created. Cases developing this distinction typically have involved problems of calculating the value of lessee's leasehold for purposes of eminent domain compensation. See McCormick, DaMages § $131 \mathrm{nn} .14$ \& 15 (1935) and cases collected in Annot., 3 A.L.R.2d 286, 326 (1949).

13. The various rationales adopted by the courts in the cases that follow are all addressed to the traditional philosophy underlying judicial enforcement of contracts. The emphasis is upon the expressed intent of the parties. See, e.g., 1 Corbin, Contracts $\S \S 1$, 13 (1950); Restatenent, Contracts \$ 2 (1932).

14. By the weight of authority, rights created under a contract cannot be protected against deprivation occurring after the termination date, even in the collective bargaining context. In System Federation No. 59 v. Louisiana \& A. Ry., 119 F.2d 509 (5th Cir. 1941), an award obtained by the plaintiff-union on behalf of its members for wrongful deprivation of seniority was vacated because the contract upon which the seniority was claimed had been set aside before the questionable discharge became effective. The issue was whether seniority rights claimed under a labor contract persist beyond the agreement. The court stated that "collective bargaining agreements do not create a permanent status, give an indefinite tenure, or extend rights created and arising under the contract, beyond its life, when it has been terminated in accordance with its proivsions." Id. at 515. Accord, Elder v. New York Cent. R.R., 152 F.2d 361 (6th Cir. 1945).

15. See, c.g., Rentschler v. Missouri Pac. R.R., 126 Neb. 493, 253 N.W. 694 (1934) (recovery limited to one year, term of contract remaining at time of wrongful discharge.) Cf., Gary v. Central of Ga. Ry., 160 S.E. 716 (1931).

16. See, e.g., Odell v. Humble Oil \& Ref. Co., 201 F.2d 123 (10th Cir. 1953) (employee limited to damages accruing for thirty days beyond the wrongful discharge where employment contract called for termination by either party upon thirty day notice.) Fisher v. Monroe, 2 Misc. 326, 21 N.Y. Supp. 995 (1893) (two week notice period; damages 
provided, recovery is also limited to the notice period. ${ }^{17}$ Where an agreement contains neither a termination date nor a notice period, and is therefore terminable at will, recovery is usually limited to nominal damages. ${ }^{18}$

Closer analogy to collective bargaining agreements may be found in exclusive agency and dealership relations, generally secured by a series of short-term contracts. Dealers' claims for lost profits resulting from the manufacturer's breach are limited to the remainder of the particular contract breached. If each contract contains both a notice provision and an express termination date, the dealer can collect only for the loss of profits he would have made during the notice period. ${ }^{19}$ As in the individual employee situation, damages do not extend even to the maximum term of the contract, let alone project to future contracts. The rule has also been applied to gasoline dealership, ${ }^{20}$ insurance agency, ${ }^{21}$ and trucking contracts ${ }^{22}$ and to equipment leases. ${ }^{23}$

To support the Brooks decision, therefore, a court must be prepared to distinguish those cases which turned upon traditional contract doctrine.

limited to two weeks' salary, interpreting the notice period as a liquidated damage provision). Cf., United Protective Workers v, Ford Motor Co., 223 F.2d 49 (7th Cir. 1955). "It is not uncommon for contracts of employment to contain a provision for termination upon a certain period of notice. In such a case, the damages are limited to the nearest date at which the employer could rightfully exercise his privilege." 5 Wirliston, Contracts $\$$ 1359, at 3815 (Supp. 1961). See also 3A CoRBin, Contracts § 647 (1960).

17. Derry v. Board of Education, 102 Mich. 631, 61 N.W. 61 (1894) (annual contract of employment terminable upon one week notice; damages limited to one week's salary). F.W. Woolworth Co. v. Petersen, 78 F.2d 47 (10th Cir. 1935) (year contract terminable upon 30 days notice; damages for breach limited to 30 days).

18. See, e.g., Cronemillar v. Duluth-Superior Milling Co., 134 Wis. 248, 114 N.W. 432,433 (1908).

19. Kessler, Automobile Dealer Franchise: Vertical Integration by Contract, 66 YALE L.J. 1135, 1186 (1957), citing Chevrolet Motor Co. v. McCullough Motor Co., 6 F.2d 212 (9th Cir. 1925) (limiting lost profits to the contract's five day notice period, although if not terminated the contract would have covered a full year).

20. Freiburger v. Texas Co., 216 Wis. 546, 257 N.W. 592 (1934) (service station proprietor-oil company contract with five day termination provision; damages limited to five days' lost profits).

21. Massachusetts Bonding \& Ins. Co. v. Johnston \& Harder, Inc., $348 \mathrm{~Pa} .512,35$ A.2d 721 (1944) (breach of 19 year old contract of indefinite duration between insurance company and local agent; damages limited to 30 day termination notice period).

It is well settled that the measure of damages for breach of contract is the value of the contract at the date of cancellation .... [I]n fixing that valuation one must consider the length of time the contract is assured of legal existence. No matter how high the earnings may be under an agency contract, the earnings will end when the contract ends.

Id. at $518,35 \mathrm{~A} .2 \mathrm{~d}$ at 724 .

22. Fife v. Great A \& P Tea Co., 166 Pa. Super. 77, 70 A.2d 369 (1950) (13 year old contract with 10 day cancellation clause between a trucker and shipper; damages limited to 10 days).

23. In re Petroleum Carriers Co., 121 F. Supp. 520 (D. Minn. 1954) (two year equipment lease with 15 day notice period; damages limited to 15 days). 
One distinction exists when the contract contains an express provision inconsistent with the termination clause. Courts have sometimes construed such a provision as indicating an intent by the parties to bind themselves beyond the apparent expiration date. ${ }^{24}$ Another distinction is available when a second contract has been agreed upon before termination of the first, even though it has not yet been signed by the parties. ${ }^{25} \mathrm{~A}$ third, recently adopted by the Supreme Court, holds that an arbitrator's award of damages for interests arising after the termination of a collective bargaining agreement is valid if the award is authorized by the agreement as construed by the arbitrator. ${ }^{28}$ Each of these distinctions is a function of the intent of the parties, and therefore is generally not available to justify an award of damages for loss of future contracts.

The most direct way a court deciding a collective bargaining case can distinguish the earlier law might be to accept the view that collective bargaining agreements are so inherently unlike usual contracts that traditional law should not be applied. ${ }^{27}$ It is possible to pinpoint three particular differences that militate against the classic emphasis upon express intent. First, at least two courts have observed that the purpose of collective bargaining agreements is much broader than that of the usual contract. ${ }^{28}$ They have concluded that collective bargaining agreements more closely resemble governing principles, and, therefore, "ought to be construed not narrowly and technically but broadly ... to accomplish ... evident aims ...." ."29 Second, it has been suggested that collective bargaining agreements frequently are made in an atmosphere of

24. See, e.g., Zdanok v. Glidden Co., 288 F.2d 99 (2d Cir. 1961), cert. denied as to issue relevant here, 368 U.S. 814 (1961). After expiration of a collective bargaining agreement, defendant removed his plant from Elmhurst, N.Y., to Bethlehem, Pa. Five workers who thereby lost their jobs sued for breach of contract. Suit was based on provisions in the agreement that employees with five years of continuous service upon layoff would be re-employed within three years if a suitable position opened and that those with less than five years' seniority were to be re-employed within two years. Defendant argued that seniority rights do not survive the agreement that created them. The court, however, held that the provisions were intended to extend guarantees beyond the agreement and found for the plaintiffs. But see A. Krock, N.Y. Times, Oct. 10, 1961, p. 42, col. 6.

This device has traditionally been used in automobile dealer cases to allow local dealers to collect damages for lost profits arising after the notice period. The conflicting contract clause has usually been a separate promise by the manufacturer to deliver a specific number of cars to the dealer who thereafter had made resale contracts for them. See, e.g., Chevrolet Mutor Co. v. Gladding, 42 F.2d 440 (4th Cir. 1930) ; Northwest Auto Co. v. Harmon, 250 Fed. 832 (9th Cir. 1918).

25. See, e.g., Jack Meilman, 34 Lab. Arb. 771 (1960).

26. United Steelworkers v. Enterprise Wheel \& Car Corp., 363 U.S. 593 (1960).

27. Two advocates of this side of an unsettled controversy are Archibald Cox and Clyde W. Summers. See Cox, The Legal Nature of Collective Bargaining Agreements, 57 Mich. L. Rev. 1 (1958) and Summers, Judicial Review of Labor Arbitration or Alice Through the Looking Glass, 2 Buffalo L. REv. 1, 17-18 (1953).

28. NLRB v. Highland Park Mfg. Co., 110 F.2d 632, 638 (4th Cir. 1940); Yazoo \& M.V.R. Co. v. Webb, 64 F.2d 902, 903 (5th Cir. 1933).

29. $64 \mathrm{~F} .2 \mathrm{~d}$ at 903 . 
great economic pressure, forcing the parties to frame the contract with intentional ambiguities in order to execute some agreement. Any attempt to ascertain a "mutual intent" from the words of such an agreement is frivolous. ${ }^{30}$ Third, it has been observed that collective bargaining agreements, unlike usual contracts, involve a great number of individuals, each of whom has his own idea of the objectives; to try to draw a general intent from so many subjective notions is as difficult as trying to identify the "intent of Congress" in passing statutes. ${ }^{31}$ These distinctions suggest that traditional doctrines emphasizing the intent of the parties may be inappropriate to the collective bargaining contract. A final distinction, perhaps the most important of all, is that collective bargaining agreements already have come under statutory regulation which, to a substantial degree, has withdrawn the parties' freedom to come and go as they please. These statutes and the policies underlying them offer the most persuasive bases upon which to fashion a new law to replace traditional contract notions in the collective bargaining area.

\section{Finding a New Theory}

The Brooks decision implies that the employer should be held liable whenever he improperly severs the relationship between himself and the union, regardless of whether the move occurs during the term of any particular contract or after its expiration. If the object of the decision was to protect the innocent party's opportunity for future contracts, a result that affords protection only against behavior that occurs while a contract happens to be in effect provides a solution so incomplete that it hardly seems worth disrupting traditional contract notions to attain. Brooks, therefore, must be read to suggest that the law should impose upon parties to certain types of contracts a legal obligation to refrain from certain conduct which would destroy the other's interest in a relationship that has existed for some time, regardless of either party's expressed intent.

To a limited extent this result has been attained by statute in some other specialized areas. Some public utilities, such as railroads, are not free to end service whenever they choose; a court or administrative agency must first determine that such cessation is not adverse to the public interest. ${ }^{32}$ During wartime or periods of acute housing shortage, lessors are prevented by statute from refusing to allow lessees to renew, except for specified reasons. ${ }^{33}$ In each case, the government has acted to prevent one party from suddenly ending its relationship with another because the other party's position makes him especially susceptible to great harm from such a termination.

30. Cox, supra note 27 , at 3-4.

31. Id. at 25 .

32. See, generally, 5 Colligr, Bankruptcy $\llbracket 77.25$ (14th ed. 1954). See also Palmer v. Mass., 308 U.S. 79 (1939) ; Matter of Denver \& Rio Grande Western R.R., 32 F. Supp. 244 (D. Colo. 1944).

33. See generally, 2 Poweli, Real Property IIf 250-52 (1950). 
A statutory scheme exists in the collective bargaining field with similar restrictive effects. Sections 8 and 9 (a) of the Labor Management Relations Act ${ }^{34}$ have tended to change collective bargaining from a traditional contract relationship to a kind of status relationship, emphasizing the character of the parties rather than their intent. Section 9(a) provides that

Representatives designated or selected for the purposes of collective bargaining by the majority of the employees in a unit appropriate for such purposes, shall be the exclusive representatives of all the employees in such unit for the purposes of collective bargaining in respect to rates of pay, wages, hours of employment, or other conditions of employment....

This statute has deprived an employer of his traditional freedom to choose a contract partner. It has imposed upon him instead a legal obligation to bargain with a particular union solely because of the status the union has attained through election. Position, not choice, brings the parties together. And if an employer refuses to negotiate with the union representing his employees, his refusal constitutes an unfair labor practice under section 8 . This means that an employer must come to the bargaining table in good faith, prepared to give the union an opportunity to make a contract, although it does not mean he has to reach agreement. ${ }^{35}$ If agreement is not reached, however, the employer may not go out and seek a new union with which to sign a collective bargaining agreement; it must have an agreement with the designated union, or it can have no collective bargaining agreement at all. ${ }^{36}$ Sections 8 and 9 (a), when read together, therefore, suggest that some kind of compulsory relationship has already been imposed upon the parties. Although the particular terms of future contracts are subject to negotiation, the parties have been placed in a position where they must at least negotiate. The statutory status of the union as exclusive bargaining agent is a valuable one, and any act which disrupts it violates the very structure and policy of the federal labor scheme.

A justification for requiring a party to pay damages for disrupting the status underlying the collective bargaining relationship may be found in the famous Lincoln Mills ${ }^{37}$ opinion, which interpreted section 301 as having superseded the common law rule disallowing specific performance of an

34. Section $8($ a) (5), 61 Stat. 141 (1947), 29 U.S.C. § 158(a) (5) (1958); § 9(a), 61 Stat. 143 (1947), 29 U.S.C. $\$ 159$ (a) (1958).

35. If accord is reached, however, courts have held that there is an obligation to follow through by signing. See, e.g., NLRB v. Nesen, 211 F.2d 559 (9th Cir. 1954). Courts have also enforced NLRB orders compelling the parties to sign contracts after all terms have been agreed upon. See, c.g., H.J. Heinz Co. v. NLRB, 311 U.S. 514 (1941).

36. The NLRB has declared it an "unfair labor practice" for an employer to remove primarily to avoid the union. The Board generally responds by ordering the employer to return to his former location, or pay employees travel expenses to the new site. See, e.g., Diaper Jean Mfg. Co., 109 N.L.R.B. 1045 (1954); Tennessee Carolina Transp. Co. Inc., 108 N.L.R.B. 1369 (1954), Rome Products Co., 77 N.L.R.B. 1217 (1948). See also 53 MICH. L. REv. 627 (1955), discussing NLRB remedies in runaway shops.

37. Textile Workers Union v. Lincoln Mi1ls, 353 U.S. 448 (1957). 
executory agreement to arbitrate. The Court explained its result with this dictum, relied upon heavily in Brooks:

We conclude that the substantive law to apply in suits under section 301 (a) is federal law, which the courts must fashion from the policy of our national labor laws .... The Labor Management Relations Act expressly furnishes some substantive law. ... Some [laws] will lack express statutory sanction but [that problem] will be solved by looking at the policy of the legislation and fashioning a remedy that will effectuate that policy. The range of judicial inventiveness will be determined by the nature of the problem. ${ }^{38}$

Lincoln Mills can be viewed as authorizing courts to consider the national labor statutes when deciding suits involving cessation of a collective bargaining relationship. And if a court finds that these statutes afford the union an enduring status right, it would be justified in fashioning a remedy to protect this right from improper abridgement. Support for the use of a damage remedy in such a situation might be drawn from the Enterprise Wheel case, ${ }^{30}$ in which the court enforced an arbitrator's decree awarding contract damages that arose after termination of the agreement. Although the majority opinion was based on the narrow ground that the court must assume the arbitrator did what the contracting parties expressly authorized him to do, the dissent ${ }^{40}$ and the lower court opinion ${ }^{41}$ declared the award invalid strictly as a violation of traditional contract law. The majority opinion thus could be construed as the first judicial step towards recognizing in futuro damages as a useful device for solving problems peculiar to the collective bargaining field and, therefore, an acceptable substitute for traditional contract doctrines. The NLRB policy awarding wrongfully discharged employees back pay covering the period after expiration of the collective agreement in force when the discharge occurred is an additional indication that an in futuro money judgment may sometimes be appropriate in the labor field. ${ }^{42}$

A court that awards damages for violation of an obligation that derives from sections 8 and 9 (a) of the Labor Management Relations Act, however, would come dangerously close to invading the primary jurisdiction of the National Labor Relations Board. Congress presumably labeled particular activities "unfair labor practices" in order to specify which problems the Board alone was to cope with. Courts therefore traditionally have declined to grant remedies for what the act declares to be an "unfair labor practice," unless that activity also constitutes a breach of contract or a tort. ${ }^{43}$ Lincoln

38. Id. at 456 .

39. United Steelworkers v. Enterprise Wheel \& Car Corp., 363 U.S. 593 (1960).

40. Id. at 599 .

41. Enterprise Wheel \& Car Corp. v. United Steelworkers, 269 F.2d 327 (4th Cir. 1959).

42. See, e.g., Victor Metal Prod. Corp., 106 N.I.R.B. 1361 (1953). Cf. Western Union Tel. Co., 83 N.L.R.B. 238 (1949).

43. Amazon Cotton Mill Co. v. Textile Workers, 167 F.2d 183 (4th Cir. 1948) (refusal to bargain collectively with union held not remedial by a court); cf. United Elec. Radio \& Mach. Workers v. International Bhd. of Elec. Workers, 115 F.2d 488 (2d Cir. 1940). 
Mills, of course, could be construed as having weakened the division between the jurisdiction of the courts and that of the Board when it invited courts to fashion remedies based on standards of the Labor Management Relations Act. A court that awards damages for termination of a going collective bargaining relationship, therefore, must read Lincoln Mills and the federal statutory scheme liberally, not only to justify protecting that going relationship, but also to extend judicial authority into the area identified as "unfair labor practices."

\section{Fashioning an Adequate Remedy}

Once a court has taken the first two steps-distinguished traditional contract doctrine and substituted a theory imposing a more permanent relationship upon parties to collective bargaining agreements-it still must fashion a remedy to enforce the new law effectively. If the remedy selected is compensatory damages, as it was in Brooks, the court must identify the actual injury suffered by the plaintiff and assign a monetary value to it. Before the company left there was a "chance" or probability that future contracts would have been made. The actual injury to the union, therefore, is the loss of this "chance" to make future contracts.

Two devices are available to calculate damages for the loss of this chance. One is an all-or-nothing method, by which the court would award damages for the full value of the future contracts if the probability that they would have been made exceeds a minimum level, and would award nothing if the probability is below that level. 44 The weakness of this method is its failure to compensate for the actual interest lost by the plaintiff, which is not the future contracts themselves, but the "probability" of entering such contracts. The other device is the classic theory of simple probability, used first by the courts of England. ${ }^{45}$ This requires reducing the probability to a numerical value and multiplying that number by the full economic value of the future contracts to the plaintiff, to ascertain the precise economic value of the probabil-

44. This technique is best exemplified by the extreme case of Pollack v. Pollack, 39 S.W.2d 853 (Tex. Comm. App. 1931), rehearing denied, 46 S.W.2d 292 (1932). In adjusting separate interests in a factory, $A$ promised to pay $B \$ 5,000$ annually for the rest of $B$ 's life, upon condition that if $A$ should predecease $B$, payments would cease and $A$ would devise by will $\$ 100,000$ to $B$. $A$ breached, and $B$ sued for full value of $A$ 's promises. The court employed actuary tables to calculate the probability of the contingency, and determined that $A$ 's life expectancy was 11.67 years at the date of trial, $B^{\prime}$ 's 14.74 . Since it was more probable that $A$ would predecease $B$, the court awarded $B$ full value of the future event $(\$ 100,000)$ plus $\$ 5,000$ for each of the next 11.67 years, less interest.

Compare Adams Express Co. v. Egbert, $36 \mathrm{~Pa}$. 360 (1860) (damages for loss of $\$ 500$ contest prize disallowed because evidence suggested plaintiff would probably not have won).

The law of tortious interference with the making of a contract has consistently adopted this approach. Compare McPeek v. Western Union Tel. Co., 107 Iowa 356, 78 N.W. 63 (1899) with Smitha v. Gentry, 20 Ky. L. Rep. 171, 45 S.W. 515 (1898). See generally 1 Harper \& Jasies, Torts $\$ 6.11$ (1956); Prosser, Torts 745-49 (2d ed. 1955).

45. Chaplin v. Hicks, [1911] 2 K.B. 786 (1911). 
ity. ${ }^{46}$ Both devices require the evaluation of two separate factors: the probability of future contracts and the full value of the future contracts to the plaintiff.

In each approach, of course, the monetary value of the damages can be calculated only as accurately as the numerical value of the probability. The probability that two given parties would have made a future contract had one party not severed the relationship is the sum of the probable non-occurrence of all factors that could prevent the contract. The key to any probability system is identifying these variables and assigning a probability value to them. To predict whether a future contract would have materialized, however, a court must first determine which factors not to consider. Obviously, if the court considered all the factors that persuaded the employer to abandon the union in the first place, the probability that there would have been a future contract will always be zero, and no damages could ever be awarded. When deciding which factors to exclude in predicting whether another contract would have been made, the court has at least two alternatives. It can exclude all factors an employer would consider in deciding to end relations with a union, thereby imposing upon the employer an absolute obligation to make no decisions that would separate him from the union. Or the court can establish a "bad faith" standard, under which it would ignore a limited number of the many factors that might influence an employer to move. This second alternative seems to comport more closely with the objectives of the Labor Management Relations Act. In either event, the number of factors remaining to be considered renders the calculation of damages a most formidable task.

In simple fact situations ${ }^{47}$ courts have been able to compute damages with "reasonable certainty" 48 by estimating the probability of a future event. As the relevant factors determining the future event become increasingly complex; however, the measure of damages becomes decreasingly certain. In the collective bargaining situation it is impossible to apply the reasonable certainty standard without precluding damages entirely. In the first place, a court would be hard pressed to identify all the factors that could preclude future

46. Rouse, Doctrine of Chances, pp. xxvii, xli (1819). The modern trend seems to be toward adopting this older technique. See, e.g., Wachtel v, National Alfalfa Journal Co., 190 Iowa 1293, 1302, 176 N.W. 801, 805 (1920) (award of nominal damages for breach of contest contract reversed) :

The measure of plaintiff's damages was the value of the contract; the value of the right to compete for one of the prizes offered ... not the value of any one of the 50 prizes offered, because the jury would have no means of ascertaining which prize she would have won, if any.

See also Note, 45 Harv. L. Rev. 585, 586 (1932); McCormicr, Damages $\S 31$ (1935); Restatement, Contracts § 332 (1932).

47. See notes 44-46 stpra.

48. Damages are recoverable for losses caused or for profits and other gains prevented by the breach only to the extent that the evidence affords a sufficient basis for estimating their amount in money with reasonable certainty.

Restatement, Contracts $\$ 331$ (1) (1932). See also 5 Corbin, Contracts $\$ 1020$ (1951). 
contracts, even under the absolute obligation standard. Apart from factors that would affect a decision by the employer to act in a way that destroys the possibility of future contracts with the union, there is a variety of factors outside the employer's control that could destroy the relationship. The union could be voted out by its members; the employer himself could be destroyed by excessive union demands, pickets, fire or embezzlement; the local union could dissolve or merge with another union; the employer could be forced to relocate by a change in zoning laws or the expiration of a lease. If the standard were merely "bad faith," the following additional possibilities would arise: contract negotiations between the parties could reach an impasse; the employer's profits could fall off so much that he would abandon the business or switch to a product line requiring the services of another union's members; allocation of economic resources could shift to force the employer to relocate nearer his source of raw materials or the market; competitive factors could dictate the adoption of automation.

Even if identification of all relevent factors were possible, the problem of estimating the probability of their occurrence seems insoluble. Nation-wide or industry-wide statistics may report the number of times some factors have occurred in the past, and this data can be projected into the future to calculate the probability of each factor occurring again. But the factors that may prevent two particular parties from making a future contract do not exist independent of each other. When the probability of one reaches a certain level the probability of others may increase or decrease, and the statistical method cannot measure this interaction in a specific factual complex. Moreover, many of the relevant factors themselves are largely products of individual attitudes and corporate policies, determining the way a particular union or employer will react to specific situations. Statistics showing how others reacted to similar situations are of even more limited value here. ${ }^{49}$

The court, of course, could adopt a less precise measure of damages, like that employed by some courts and urged by many leading writers in tort law, by giving the trier of fact wide flexibility to weigh the evidence as a whole, rather than try to focus on each of the many variables, and to decide whether future contracts would, more likely than not, have materialized. ${ }^{50}$ The dif-

49. Statistics are also of very limited help in determining the number of future contracts that would have materialized. The farther into the future present statistics are projected, the less accurate is the prediction based upon them. Corbin approves of decisions arbitrarily limiting damages to a few years for breach of exceptionally long running contracts (1000 year leases, for example), primarily because evidence projecting far into the future is rarely available. See 5 Corbin, Contracrs $\$ 1024$ (1951), and cases cited therein.

50. This more liberal estimation of the probability of future events occurs frequently in wrongful death actions and suits involving loss of plaintiff's future earning capacity. See generally, 2 HARPER \& JAMIES, TORTS $\$ \S 25.8,25.14$ (1956). But the rule of certainty has precluded many states from evaluating such items as a lost chance, and its suspension is being urged in some of those areas as well. Id., \$25.3. 
ficulties in trying to identify and predict all the relevant factors might thereby be avoided, but one other problem still remains.

However the court determines the probability of future contracts, it must face the challenge of compensating for the loss of that probability. This requires an estimation of the full value of the future contracts to the plaintifi. ${ }^{51}$ Expected dues-the basis of the Brooks award 52 - do not represent the union's real interest in future agreements. Theoretically, the local union returns most, if not all, the dues it receives to the employees in the form of services rendered under each collective agreement. If there are no further contracts, both the income and the expense ultimately will terminate, and the net loss to the union itself will be close to nothing.

An accurate description of the union's interest in a collective bargaining agreement would have to include the elements of prestige and institutional strength. These frequently are the benefits the union seeks when it spends enormous sums of money to organize new shops. The more agreements a union makes, the more powerful a bargaining agent it becomes, and the better it can perform its function in the economy. When a union is improperly deprived of an opportunity to continue a contractual relationship, therefore, the injury it suffers may not lie in the loss of any monetary income, but in the damage to its stature as a representative agent. Money damages may help a union re-organize in another factory, but they will not make the union whole. Neither compensatory damages, if calculable, nor punitive damages satisfactorily restore the inevitable loss of prestige and power that results when an employer abandons his relations with a union.

The most appropriate solution is probably the use of an equitable remedy, by which the court can order the employer to return to his original location if he already has begun to move, or prevent him from moving if he has not yet done so. But if a court adopts such a policy, it has placed itself in the position of duplicating a remedy the NLRB regularly can provide. ${ }^{\text {t3 }}$

The damage remedy is thus inappropriate, not only because it is difficult to calculate accurately, but because it does not reflect the actual loss to the union. The appropriate remedy, equitable relief, on the other hand, can better be administered through the expertise possessed by the NLRB, which long has been granting such a remedy. ${ }^{54}$ Even if there are sound economic or policy reasons for protecting a union's interest in the continuation of its collective bargaining status with an employer, there seem to be no adequate reasons for this protection to stem from the courts.

51. This determination is necessary to apply either of the two methods available to translate the probability of a future contract into dollars and cents. See text at notes 44-46 supra.

52. See note 6 supra.

53. See note 36 supra.

54. See note 36 supra. 